University of South Florida

DIGITAL COMMONS Digital Commons @ University of @ UNIVERSITY OF SOUTH FLORIDA South Florida

$11-1-2002$

\title{
Commuter Choice Managers and Parking Managers Coordination
}

CUTR

Follow this and additional works at: https://digitalcommons.usf.edu/cutr_nctr

\section{Recommended Citation}

"Commuter Choice Managers and Parking Managers Coordination," National Center for Transit Research (NCTR) Report No. CUTR-NCTR-RR-2002-22, Center for Urban Transportation Research, University of South Florida, 2002.

DOI: https://doi.org/10.5038/CUTR-NCTR-RR-2002-22

Available at: https://scholarcommons.usf.edu/cutr_nctr/115

This Technical Report is brought to you for free and open access by the National Center for Transit Research (NCTR) Archive (2000-2020) at Digital Commons @ University of South Florida. It has been accepted for inclusion in Research Reports by an authorized administrator of Digital Commons @ University of South Florida. For more information, please contact digitalcommons@usf.edu. 


\title{
PUBLIC TRANSPORTATION SYNTHESIS SERIES
}

\section{Commuter Choice \\ Managers and Parking \\ Managers Coordination}

\author{
Francis Wambalaba, $\mathrm{PhD}$ \\ Principal Investigator \\ Kimberlee Gabourel \\ Graduate Student Assistant

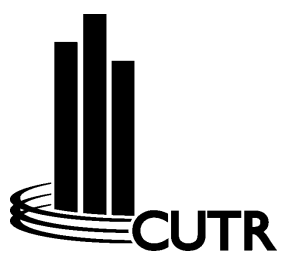

November, 2002 



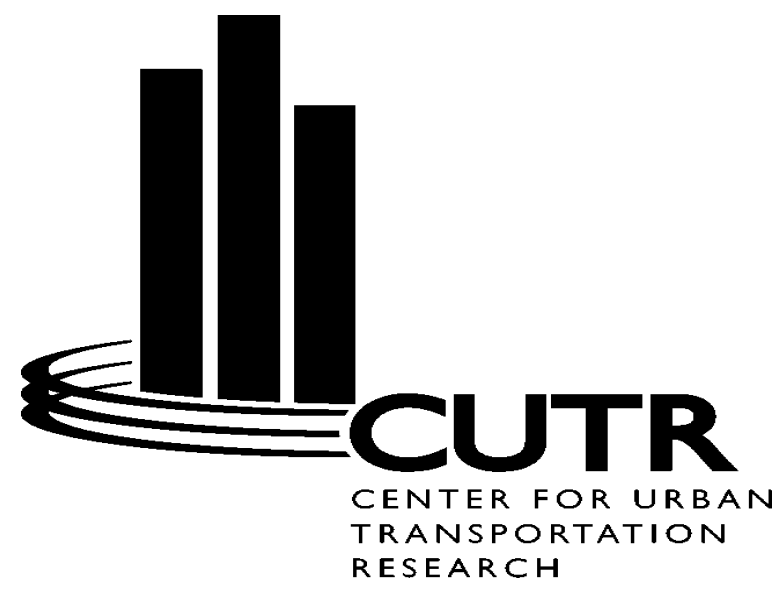

\section{CENTER FOR URBAN TRANSPORTATION RESEARCH \\ University of South Florida \\ 4202 E. Fowler Avenue, CUT100 \\ Tampa, FL 33620-5375 \\ (813) 974-3120, SunCom 574-3120, Fax (813) 974-5168}

Edward Mierzejewski, P.E., CUTR Director

Joel Volinski, NCTR Director

Dennis Hinebaugh, Transit Program Director

The contents of this report reflect the views of the author, who is responsible for the facts and the accuracy of the information presented herein. This document is disseminated under the sponsorship of the Department of Transportation, University Research Institute Program, in the interest of information exchange. The U.S. Government assumes no liability for the contents or use thereof. 
TECHNICAL REPORT STANDARD TITLE PAGE

\begin{tabular}{|c|c|c|c|}
\hline $\begin{array}{l}\text { 1. Report No. } \\
473-134\end{array}$ & 2. Government Accession No. & \multicolumn{2}{|c|}{ 3. Recipient's Catalog No. } \\
\hline \multirow{2}{*}{\multicolumn{2}{|c|}{$\begin{array}{l}\text { 4. Title and Subtitle } \\
\text { Commuter Choice Managers and Parking Managers } \\
\text { Coordination: Public Transportation Synthesis Series }\end{array}$}} & \multicolumn{2}{|c|}{$\begin{array}{l}\text { 5. Report Date } \\
\text { November } 2002\end{array}$} \\
\hline & & \multicolumn{2}{|c|}{ 6. Performing Organization Code } \\
\hline \multicolumn{2}{|c|}{$\begin{array}{l}\text { 7. Author(s) } \\
\text { Kimberlee Gabourel and Francis Wambalaba, PhD }\end{array}$} & \multicolumn{2}{|c|}{ 8. Performing Organization Report No. } \\
\hline \multirow{2}{*}{\multicolumn{2}{|c|}{$\begin{array}{l}\text { 9. Performing Organization Name and Address } \\
\text { National Center for Transportation Research } \\
\text { Center for Urban Transportation Research } \\
\text { University of South Florida } \\
4202 \text { E. Fowler Avenue, CUT 100, Tampa FL 33620-5375 }\end{array}$}} & \multicolumn{2}{|l|}{ 10. Work Unit No. } \\
\hline & & \multicolumn{2}{|c|}{$\begin{array}{l}\text { 11. Contract or Grant No. } \\
\text { DTRS } 98-9-0032\end{array}$} \\
\hline \multirow{2}{*}{\multicolumn{2}{|c|}{$\begin{array}{l}\text { 12. Sponsoring Agency Name and Address } \\
\text { Office of Research and Special Programs } \\
\text { U.S. Department of Transportation, Washington, D.C. } \\
20690 \\
\text { Florida Department of Transportation } \\
605 \text { Suwannee Street, MS 26, Tallahassee, FL } 32399\end{array}$}} & \multicolumn{2}{|c|}{$\begin{array}{l}\text { 13. Type of Report and Period } \\
\text { Covered }\end{array}$} \\
\hline & & \multicolumn{2}{|c|}{ 14. Sponsoring Agency Code } \\
\hline \multicolumn{4}{|c|}{$\begin{array}{l}\text { 15. Supplementary Notes } \\
\text { Supported by a grant from the Florida Department of Transportation and the U.S. } \\
\text { Department of Transportation }\end{array}$} \\
\hline \multicolumn{4}{|c|}{$\begin{array}{l}\text { 16. Abstract } \\
\text { Shared use park and ride represents a unique approach for addressing parking } \\
\text { problems, and can offer substantial savings in land and development costs. One } \\
\text { of the fundamental factors that determine the success of this approach is the level } \\
\text { coordination that exists between parking managers and transportation } \\
\text { coordinators. This research investigates this coordination through the review of } \\
\text { literature and feedback from stakeholder and documents current practices, } \\
\text { anticipated developments and the level of coordination between Park and Ride } \\
\text { Managers and Commuter Choice Managers. }\end{array}$} \\
\hline $\begin{array}{l}\text { 17. Key Words } \\
\text { Shared use park and ride, park } \\
\text { and ride }\end{array}$ & $\begin{array}{l}\text { 18. Distribution Statement } \\
\text { Available to public th } \\
\text { Technical Informatior } \\
\text { Port Royal, Springfiel } \\
487-4650\end{array}$ & $\begin{array}{l}\text { Igh the } \mathrm{Na} \\
\text { ervice (NT } \\
\text { VA } 22181\end{array}$ & , 5285 \\
\hline $\begin{array}{l}\text { 19. Security Classif. (of this report) } \\
\text { Unclassified }\end{array}$ & $\begin{array}{l}\text { 20. Security Classif. (of this page) } \\
\text { Unclassified }\end{array}$ & 21. №. of pages & 22. Price \\
\hline
\end{tabular}

Form DOT F 1700.7 (8-69) 


\title{
Acknowledgments
}

This report is part of the Public Transportation Syntheses Series, prepared by the National Center for Transit Research through the sponsorship of the Florida Department of Transportation and the U.S. Department of Transportation.

\section{FDOT Project Team:}

Tara Bartee, Planning Administrator, Florida Department of Transportation

\section{CUTR Project Team:}

\author{
Principal Investigators: \\ Kimberlee Gabourel \\ Francis Wambalaba, $\mathrm{PhD}$ \\ Principal Author: \\ Kimberlee Gabourel \\ Contributors: \\ Julie Goodwill, \\ Dennis Hinebaugh, \\ Joel Volinski
}

Appreciation is expressed to the following individuals for their helpful comments:

Tom Locke, University Mall

Keith Gregory, Veterans Administration

Karen Gard, Busch Gardens

Theresa Harrison, Regional Transit System

Sheron Abernathy, Hillsborough Area Regional Transit

David Martin, Jacksonville Transportation Authority

Chris Leffert, Lee County Transit Division

Susan Hancock, Manatee County Area Transit

George Mendez, Manatee County Area Transit

Frank Talleda, Miami-Dade Transit

Tony Walter, Central Florida Regional Transportation Authority

Bill Steele, Pinellas Suncoast Transit Authority

Hank Cusack, Sarasota County Area Transit

Al Tisnes, South Florida Vanpool

Jeff Horton, Florida State University

Tom Dornfeld, Oaks Mall

Gary Bales, Kmart Stores

Sonny Mesnith, Kmart Stores 


\section{Table of Content}

Executive Summary

Introduction \& Methodology

The Overview

Brief Review of Issues

Background

The Current Practices

Methodology

Role of Entity Survey

Literature Review

Park and Ride Related Literature

Review of P \& R Literature

Steven Smith Study

Wilbur Smith Study

Urban Transportation Monitor Studies

Lease Agreements

Limitations to Shared Use P\&R

Similar Project Studies

Public Transit Access to Private Property

FDOT Planning Manual for P\&Rs

Techniques

Observations

Stakeholder Feedback

Findings From Parking Managers/Private Property Owners 19

Findings From Transit Agencies 20

Related Findings 21

Other Unanticipated 21

Conclusions and Recommendations 23

Appendix 26

Lease Agreements 26

Survey Questions $\quad 29$

Listing of Service Providers 31

Listing of Parking Managers 33

Framework for Shared Use P \& R Analysis 34

Footnotes 


\section{Executive Summary}

Shared use park and ride is defined as park and ride spaces that can be used to serve two or more individual land uses without conflict or encroachment. It represents a unique approach for addressing parking problems, and can offer substantial savings in land and development costs. One of the fundamental factors that determine the success of this approach is the level of coordination that exists between parking managers and transit agencies. Commercial centers and private property owners/managers have traditionally not been enthused or willing to participate in shared use park and ride opportunities based on the assumptions that park and rides create potential for criminal activities, take away space from customers, and may lead to increased insurance rates. Transit agencies on the other hand, believe that there is potential for economic benefits for property managers/owners and the agencies themselves, as well as improved transit service and shopping convenience for their customers.

This report is a synthesis of literature on coordinating parking arrangements exist between park and ride managers and transit agencies. It highlights varying interests among stakeholders and respective perceptions about the benefits and challenges of such a relationship. It also provides a baseline for further study to determine the validity of such assumptions.

The first part of this study involves a literature review in two areas:

- a review of nationally published studies of shared use park and ride

- a review of studies regarding public transit access to private property as well as shared use park and ride in Florida

The literature search revealed that responses to the questions about incentives suggest three key themes:

1. The majority of the concerns are related to the physical attributes of the transit vehicles and the damage that can be caused due to those attributes.

2. Maintenance is one of the most important incentives to developers, and also one of the most frequently given incentives provided by transit agencies. Consequently, this should be a focus area in negotiations.

3. There is need for education among the players in order to alleviate some of the misperceptions of transit services and patrons.

The second part is a review of direct feedback from participating private property developers, or owners and managers of shared use Park and Ride in Florida, as well as feedback from transit agencies and other rideshare agencies in Florida.

Feedback from private property owners/managers indicated that the most important incentives that can be offered to assure a better working relationship with transit agencies include installation of amenities, maintenance of stops on site, periodic cleanings, and concrete pads. Major concerns included:

- Perceived high levels of crime

- Ridership that was not part of their customer base 
- Damage to asphalt

Feedback from transit agencies indicated that:

- Property managers, developers or owners are more inclined to agree to coordinate with transit agencies when they are assured of more potential customers

- There is not one single incentive that can be offered to private property developers, owners or managers. However, the highest ranked incentives include liability insurance, installation of amenities and maintenances of bus stops on-site.

- Transit agencies may be reluctant to approach property managers due to a fear that property managers will say no or renege on past agreements.

While the goal of this study is to investigate existing literature and report on the coordinating aspects of shared use park and ride and its effects, it also includes some basic recommendations regarding what can be done to maintain, and perhaps increase, the coordination level between all transit agencies and private property managers or owners.

The literature indicated that the following guidelines must be used when implementing shared use Park and Ride:

- $\quad$ Each parking space should be usable by all parkers.

- The facility should be designed to accommodate significant inbound and outbound traffic flow at one or more periods of the day.

- Because of the variety in types of parkers, the facility must have effective signing, markings, and other communications tools.

The core findings of the study revolved around conflicting perceptions between transit agencies and P\&R managers. It was evident that most transit agencies perceived that businesses that offer P\&R opportunities gained economically from users who end up shopping there. However, most property managers perceived that users of $\mathrm{P} \& \mathrm{R}$ facilities did not generally shop there and indeed took up space that could be used by their customers, and to some extent, may engage in criminal activity at their business. Further findings included poor communication between transit agencies and P\&R managers. In some cases, new management at shopping centers was not aware that their parking lot was a P\&R facility, while a handful of transit agencies were uncomfortable to highlight such an arrangement, lest P\&R managers realize the situation and opt to discontinue the arrangement.

The shared use park and ride approach has been plagued with perceptions which in some cases have become accepted myths. Until private property owners and developers are presented with the facts and successful examples of collaboration, they may likely continue with these myths and operate at an economic disadvantage to their own goals. Responding to developers and owners' own self-interest is likely to be more effective than an appeal to a sense of civic responsibility. Likewise, transit agencies, need to address the concerns of the park and ride owners. The report suggests that the following 
steps be taken by transit agencies to ensure effective coordination with property managers, owners and developers:

1. Transit agencies should contact the local government explaining the proposed coordination and try to gain support

2. Transit agencies should approach the property developer/manager/owners

3. If the developer/manager/owner agrees, sign a legal enforceable agreement

4. Transit agencies should meet with the developer/manager/owner to design the routes, location of stops and possible passenger amenities 


\section{Introduction and Methodology}

\section{Introduction}

This research synthesis investigates the existence of coordination between property managers and transit agencies primarily through the review of existing literature. For the purpose of this report the terms commuter choice managers and transit agencies are used interchangeably. Likewise, the terms private property managers, owners and developers are used interchangeable. In addition, the study sought supplementary feedback from stakeholders through a survey questionnaire.

This study documents current practices, and anticipated developments in the level of coordination between Park and Ride Managers and Commuter Choice Managers. Like most parking strategies, shared use parking must be viewed from the perspective of strategies that influence and affect urban form, its planning decisions being coordinated with land use planning, economic development planning, and other form determinants.

This research will examine, review, and document the factors that make the interaction between transit agencies and P\&R managers successful. The research outlines the nature of the current relationship. Hence, it provides valuable information to transportation officials, the engineering community, developers, shopping-center management, and government officials regarding effective practices in coordinating shared use park and ride.

\section{The Overview}

For ease of use, this report has been organized into four main sections covering specific areas of effective coordination between park and ride Managers and Commuter Choice Managers. The first section introduces and defines the issues along with the methods incorporated in gathering the necessary information. The second section explores the literature on shared use park and ride shared use parking and ends with a critical analysis of how practitioners are utilizing shared use park and ride. The third section summarizes and analyzes answers to the survey questions from transit coordinators and P\& R managers and owners. Finally, based on this previous discussion, the fourth section presents conclusions and recommendations for effective coordination of shared use park and ride.

\section{Brief Review of Issues}

The key issues arising from this study include 1) differing perceptions of transit agencies and P\&R managers, 2) communication dilemmas and 3) the fact that some programs are ongoing with promising results. Commercial centers and other property managers harbor several negative perceptions about transit riders; hence they have been unenthused and unwilling to participate in shared use park and ride. Similarly, communication has been nonexistent or limited between transit agencies and P\&R managers. Despite the disinterest expressed by many property managers, some commercial centers and private 
properties agree to be used as park and ride locations. Others are used without any consent from P\&R mangers. Unlike many P\&R managers, transit agencies believe that there is potential for economic benefits to be derived by all involved parties when shared use park and ride strategies are utilized.

\section{Background}

Efforts to manage travel behavior have become an increasingly important element of transportation policy in the United States. In particular, recent environmental and transportation planning legislation such as the Clean Air Act, Intermodal Surface Transportation Efficiency Act of 1991 (ISTEA) and Transportation Equity Act for the $21^{\text {st }}$ Century (TEA-21) have stimulated significant voluntary and regulatory attempts to reduce the rate of solo driving. The rapid suburbanization of housing and employment has resulted in more trips to work, longer commutes and frequent travel to low-density workplaces (US Department of Transportation, 1995). These societal trends would tend to favor solo driving over other means of travel to work (Baldassare, Ryan, and Katz, 1997).

Similarly, the introduction of transportation control measures (TCM) as a part of the Clean Air Act has sought to mitigate the effects of solo driving on the environment through programs such as carpooling, park and ride (P \& R), ridesharing, high occupancy vehicle lanes (HOV) and telecommuting, to name a few. park and ride lots are an increasingly common element of many areas' plans for air quality conformity (Allen, 1996). It is widely recognized that parking policy plays an important role in urban management (Visser and Van der Mede, 1986). Parking policy measures not only affect the parking system, but also generate impacts to the transport and socioeconomic system of a city (Tsamboulas, 2000). Given the fact that the cost for building parking lots is very high compared to shared use $P \& R$, it should be logical to anticipate that Commuter Choice Coordinators such as transit agencies would favor using them versus building their own P\&Rs. However, because of real and perceived challenges, this strategy has not been used to its optimal level. There have been limited studies done to explore the role of shared use P\&R for users and stakeholders.

\section{The Current Practices}

The term P\&R is most usually applied to a dedicated transit service linking a purposely built car parking lot for transit users and other high occupancy rideshare alternatives. By making it easier to carpool or use transit, park and ride lots should theoretically reduce the number of persons driving alone to work, school, shopping, and entertainment. Volumes of literature exist on where park and ride is appropriate and how to select suitable locations; all agree that car parks consume a lot of space and require ground maintenance, lighting and surveillance, land acquisition, and construction elements. To alleviate some of the costs, much of the literature suggests that shared parking or joint use parking should be pursued, whereby local authorities, developers, or private sector contractors as well as non profit organizations volunteer some spaces in their parking lots for transit and rideshare commuters to park their cars. This partnership approach 
encourages "parking spaces that can be used to serve two or more individual land uses without conflict or encroachment" thereby offering substantial savings in land and in development costs (Barton-Aschman Associates, Inc.). One example of this approach would be a shopping center with designated parking spaces for park and ride use.

Shopping centers, churches, cinemas, airports, theme parks and universities etc. have been prime targets for this partnership approach. Differing opinions arise on this issue from both parking managers and transportation coordinators. Some supporters believe that the concept is a panacea for all parking problems, because it provides an opportunity for a mutually beneficial relationship for parking managers and transportation coordinators. Others view the relationship as non-economic and to some extent, parasitic. The argument has not been defused since little has been done to document or quantify the effects of park and ride facilities at businesses.

\section{Methodology}

To investigate the level of coordination between transit agencies and park and ride managers and determine possible impacts of shared use park and ride on commute levels, two different sources of measurements are used in this report. Specifically, a combination of qualitative and quantitative methodologies were employed, i.e., literature review and agency survey. Each method expanded upon, clarified or illustrated the other. Kidder and Fine (1987) suggests that multiple and different sources of information, methods and theories strengthen data collection and analysis. ${ }^{1}$ Likewise, Light and Pillemer (1984) state that using a combination of narrative and quantitative procedures is superior to using either alone ${ }^{2}$

The sample population for the survey was obtained from transit providers in urban areas within the state of Florida. These addresses were compiled into a mailing list of transit providers, park and ride property managers, and locations. Initially, the sample population was informed about the impending survey by both telephone calls or mailed or emailed letters. Later on, interviews were held and the surveys distributed.

Articles, reports, books, and manuals on shared use park and ride were collected, examined, and summarized. The study included an extensive review of local, state, and national literature pertaining to Commuter Choice Managers and Parking Managers coordination. Several extensive searches were conducted using the TRIS (Transportation Research Information Service) literature database, CUTR's Resource Information Center (CRIC), as well as search engines such as Lexis/Nexis, First Search, Eureka, and Uncover. The purpose of the literature review was to identify issues and strategies, along with finding park and ride sites at business and commercial sites so as to learn about coordination initiatives at these sites. The review yielded limited studies pertaining to the coordination between park and ride Managers and Commuter Choice Managers. Based on the results of this data collection effort, the results of the review have been synthesized. It should be noted that the literature presented in this review does not include all the data reviewed, as some data were discarded due to their irrelevance. 


\section{The Role of Entity Surveys}

The study also solicited feedback from P\&R managers as well as transit agencies to complement the literature review. For this study, both the questionnaire and face-to-face methods were chosen.

Specifically, the experiences of park and ride managers in relation to public transit bus access onto private property were reviewed through a face-to-face survey and questionnaire. A 14-question evaluation instrument was developed. The survey was comprised of two sections, one addressing property managers, and the other addressing transit agencies. The first six questions were phrased to provide property managers with the opportunity to check-off responses, circle issues of most importance, and least importance and give comments. The second section consisted of eight questions phrased to provide transit providers with the opportunity to check-off responses and give comments.

The study identified twenty nine transit agencies in Florida and obtained their mailing addresses or e-mails and requested them to provide information about the locations of their park and rides; identify which ones were shared use park and rides at commercial centers; the contact person at the park and ride site and asked for permission to contact park and ride managers. The transit agencies indicated thirty-six shared use park and rides. These properties included two bus stations, nineteen shopping centers, one race track, a retirement home, one conference center, seven shopping malls, two capital buildings, one home depot, one church and one museum. In addition, there were five confirmed formal agreements and five confirmed informal agreements. Likewise, eleven parking managers were indicated.

After receiving this information, several attempts were made to follow up with nonrespondents. Surveys were then sent to both park and ride managers and transit agencies. The feedback received included written and both verbal discussions on the phone or faceto-face interviews.

The survey was comprised of two sections and respondents were asked to answer which situation was applicable. The purpose of the first section was to identify major concerns of private property owners/managers as they relate to allowing direct vehicle access to public transit providers as well as allowing or continuing to allow a shared use park and ride lot on their property. Elements of the survey included feedback about the types of properties managed, owned, or developed, level of importance of different issues, the level of importance of incentives, and the nature of experiences with different issues.

The response rate of the survey was low despite the many efforts made to contact both property managers and transit agencies. Reminder surveys were mailed and emailed. Likewise, reminder postcards along with the survey were emailed and mailed indicating to both property managers and transit agencies the importance of the study and prompting them to respond. Transit agencies that did not respond did not give an explanation for their nonparticipation. However, most property managers who declined to participate 
claimed that the study would have no significance to them since park and ride facilities only took up their limited parking spaces and encouraged crime. Consequently only two property managers agreed to fill out the survey. To further exacerbate the problem of limited property managers' responses, four transit agencies asked that the property manager not be contacted due to fear that if the presence of the park and ride on the properties were brought to light, property mangers would renege, be uneasy, or demand further reimbursements. 


\section{Literature Review}

\section{Park \& Ride Related Literature}

The review of literature in this study has been divided into two segments. This first segment reviews literature specific to shares use park and ride. The second segment reviews literature related to arrangements for locating other public transportation facilities such as bus stops on private commercial properties such as shopping malls.

\section{Review of P\&R Literature}

In a report conducted for the Urban Land Institute by Barton Associates, in 1983, shared use park and ride is defined as park and ride spaces that can be used to serve two or more individual land uses without conflict or encroachment. ${ }^{3}$ The authors note that shared use park and ride only works with developments that meet certain conditions:

- When there are variations in the peak accumulation of parked cars, due to the time differences inherent in the activity patterns of adjacent or mixed land uses

- When the land uses are so related that people are attracted to two or more of them on a single auto trip to the development or area such as shopping and dining at the same complex

The authors concluded with the following list of guidelines for implementing shared parking:

- $\quad$ Each parking space should be usable by all parkers

- The facility will have significant inbound and outbound traffic flow at one or more periods of the day

- Because of the variety in types of parkers, the facility will be more sensitive to effective signing, markings, and other communications tools

- Shared parking can be used as evidence for a zoning procedure and as a development design tool

The Federal Highway Administration report, Parking Management Tactics: A Reference Guide Volume III also contributed to the literature on conditions that must be met for shared use park and ride to be feasible. ${ }^{4}$ These include:

- The proposed joint parking facility should be close to each participating land use

- The time periods during which each development would use the parking facility should not overlap

- There should be a legally enforceable agreement between each participating developer to ensure that the parking facility is built and operated in accordance with local zoning requirements 
The 1982 Public Technology Inc. - USDOT sponsored research The Coordination of Parking with Public Transportation and Ridesharing further enhanced the literature on shared use park and ride. ${ }^{5}$ The authors defined shared use park and ride as a strategy that relocates the supply of parking from the city center to outlying areas, thus eliminating the need to provide parking in the city. Likewise, the authors noted that automobiles are used primarily for collection in low-density residential areas, while express buses, rapid transit, or shuttle services are used to complete the trips.

Finding appropriate lot locations for this approach is difficult. Consequently, practitioners prefer to use existing parking facilities at churches, community centers, and shopping centers rather than building a new parking facility. This is especially true since the cost of using existing parking lots is cheaper than creating a new park and ride facility, typically ranging from $\$ 7,000$ to $\$ 25,000$ per parking space depending on the location and type of structure.

\section{Steven Smith Study}

In a Maryland study, Steven Smith (1983) conducted a survey of shared use park and rides at three shopping centers in Montgomery County, Maryland with the sole purpose of quantifying the effect of shared use park and ride facilities on commuter travel and shopping behavior. ${ }^{6}$ The study surveyed users at Montgomery Mall and Wheaton Plaza, which were both designated as formal park and rides, and Aspen Hill Shopping Center, which had an informal agreement. Aspen Hill Shopping Center consists of a grocery store, drug store, and clothing store as well as a variety of smaller shops.

The survey addressed issues of frequency of use of park and ride; reasons for parking in the park and ride; alternative mode choices if the park and ride was non-existent; use for shopping in the vicinity; amount spent at shops; alternative shopping choices if the park and ride had been non-existent; frequency of use of the stores; and amount spent at stores in an average week. Interviews were held orally or respondents were given the questionnaire with mailers during peak hours of 6:30 and 9:00 a.m. Of the five hundred fifteen respondents, Aspen Hill accounted for one hundred twelve responses; Montgomery Mall accounted for two hundred fifty six; and Wheaton Plaza accounted for one hundred forty seven. The respondent rate was fifty to sixty percent.

In the study, sixty five percent of the respondents indicated that they parked in the park and ride five days a week, while eighty two to ninety five percent indicated that they parked at least three to four days. When asked what alternative mode choice would have been taken if the park and ride was non-existent, between seventy four and eighty two percent of respondents from Aspen Hill and Wheaton Plaza indicated that they would have caught the same bus at a different location or carpooled. Ten percent indicated that they would have driven all the way to work. In the case of Montgomery Mall, up to thirty percent indicated that they would have driven all the way to work. The author asserts that the difference in results between Montgomery Mall and Wheaton Plaza and Aspen Hill is due to the fact that both Wheaton and Aspen are situated near a multitude 
of retail uses while Montgomery Mall is relatively isolated from other sources of parking. The author also noted that a park and ride might divert some individuals from single occupant vehicles, but many would still find some other informal park and ride arrangements.

Moreover, forty four percent at Aspen Hill, forty two percent at Montgomery Mall and twenty five percent at Wheaton Plaza indicated that they shopped at the shopping center. Aspen Hill's higher percentage rate might be due to the fact that it was the closest to the stores and had a combination of grocery and drug stores. In addition, Wheaton Plaza's low percentage might have been due to the fact that it was farthest away from the shopping facilities. The average purchases were \$14.10 at Aspen Hill, \$25.26 at Montgomery Mall and $\$ 16.30$ at Wheaton Plaza. In order to calculate the average daily purchase amount per park and ride user, Smith multiplied this purchase amount by the percentage of those P \& rPark and ride users shopping at the center. He concluded that the average daily amount spent per park and ride user for Aspen Hill was \$6.20, \$10.61 for Montgomery Mall and \$4.08 for Wheaton Plaza.

Furthermore, when asked about alternative shopping choices if the park and ride was non-existent, between eight and twenty four percent of the respondents indicated that they would have stopped by on the way to or from work anyway. Three to fifteen percent responded that they would have returned to the same location at a different time. The majority of the respondents indicated that they would have shopped at a different location, while twelve to twenty two percent indicated that they would not have made the purchase.

Smith then calculated the average daily purchase that can be attributed to the presence of the park and ride lot. The author calculated the percentage of shopping trips that could be legitimately claimed as an increment caused by the presence of the park and ride lot by summing the percentages of items not bought and items bought at different locations. These percentages were then multiplied by the daily purchases at each location.

Consequently, the decision by shopping center operators to allow commuters to use the parking lot would increase daily shopping center sales per commuter by $\$ 4.53$ for Aspen Hill, \$7.75 for Montgomery Mall and \$2.73 for Wheaton Plaza.

The author hypothesized that an additional benefit of the fringe lot to shopping centers is the displacement of trips from the peak parking time to a period of less demand. If the displacement is significant this could justify the reduction in parking requirements for the centers thereby resulting in an economic savings in construction of parking. To test this hypothesis the author, asked respondents that shopped where they would have obtained their purchases had the park and ride been non-existent. For those respondents who would have bought their purchases at the same location, eighty four percent indicated that they would have made the purchases on the weekend. Forty percent responded that they would have gone in the afternoon, which is the peak parking time. For those who would have bought their purchases at a different location, seventy five percent indicated that they would have made the purchase on a weekday. Sixteen percent indicated that they would have made the purchases between 12:00 and 4:00 p.m. near their work location. 
Consequently, the diversion of shopping trips from the peak shopping period is small. Hence, the reduction in the number of parking spaces is not justified since the hypothesis is nebulous.

Smith contends that there can be a significant economic benefit to shopping center operators for allowing commuter parking to occur on their parking lot. The survey results indicated that between twenty-five and forty five percent of the park and riders shopped at the shopping center, and two thirds of these shoppers were induced or diverted from other shopping locations. Moreover, the presence of park and ride activity caused a $\$ 5$ increase in sales per person per day. Hence, as long as there is adequate parking supply for all customers, benefits will be derived by the shopping center operators. Commuters will benefit since work and shopping trips are easily linked. Likewise, the public benefits since there is a reduced need for additional parking facilities and reduced vehicle travel.

\section{Wilbur Smith Study}

In late 1983, the Planning Journal published a special report written by Wilbur Smith entitled What's New in Parking, which explored parking trends, ideas, and solutions. Smith states that, "clearly the need for parking will continue to grow. Parking needs are likely to fluctuate, depending on such variables as the extent to which transit systems are improved, the health of the central business districts, and the state of local economies." 7

The report takes a broad look at parking based on an updated view of current developments in towns and cities, in energy, transportation, economics, environmental problems and more. The author asserts that it should come as no surprise to the casual observer of transportation and travel patterns that the private car continues overwhelmingly to be the number one choice of people for all trip purposes. In tandem, most cars continue to be parked for eighteen to twenty two hours out of the day.

According to the report, the costs of constructing and operating parking facilities of all kinds are high. Likewise, other possible barriers to building parking facilities have included finding adequate transit service, insufficient rideshare programs, lack of suitable incentives, and perceived security concerns. Fortunately, in recent years some land uses and activities have required less parking. This phenomenon is due to a combination of a jump in fuel prices, higher car operating costs, higher parking fees, and in some cases government policy.

In an effort to reduce traffic congestion and solo-driving, preferential parking is a growing phenomenon geared at encouraging high occupancy vehicles (HOVs) such as carpool and vanpools. The Wilbur Smith report notes that parking rates are also being used as tools in favor of HOVs. The study revealed that due to the high costs of parking construction and operations, the emphasis is on mixed-use projects built by the public and private sectors jointly. Finally, Smith concludes that parking will continue to evolve as the economy fluctuates, as competitive factors intervene and as conflict pressures are felt. 


\section{Urban Transportation Monitor Studies}

During the early 1990s, the Urban Transportation Monitor published several articles exploring the characteristics of a successful park and ride. The articles defined park and ride and explored the essentials for a successful P\&R program, provisions for P\&R, best practices, technological support and possible pitfalls to avoid. ${ }^{8}$

On April 13, the editor of the Urban Transportation Monitor discussed a study in which several nationwide surveys were conducted by mail in March 1990 to obtain the characteristics of the most successful park-and ride-lot operated by transit agencies. The questionnaires were sent to 65 of the largest transit agencies with a forty six percent respondent rate. Park and Ride was found to be one of the few transit strategies that was successful in serving low and medium density suburban areas (Urban Transportation Monitor 1990). The findings indicate that successful, park and rides possess the following elements:

- Good location (relative to catchment area and highway)

- Easy access to highway

- Free parking, with high parking cost in central business district (CBD)

- A congested corridor

- Good quality transit (high frequency, high speed)

- Multi-function site (adjoining shopping or entertainment facilities e.g. superstore, cinema, stadium, hotel and conference center)

- Secure (well-lit, observant on-site personnel)

In the April $27^{\text {th }}$ editorial, the editorial discussed a study that looked at where P\&R is most appropriate. The study noted six suitable locations as follows:

1. Free-standing town/city (to bring out-of-town residents together at the edge of the built-up area in viable numbers for bus travel)

2. Attractive town center (somewhere people really want to go, even if they cannot take their car)

3. Town center parking that is expensive and in short supply (more convenient and cheaper to use P\&R)

4. Rural tourist "honey pots" (heritage designations, narrow lanes and crowded resorts)

5. Parkway rail stations (rail heading for long-distance travel)

6. Airports (park and fly)

Similarly, the study revealed that the best P\&R locations are

- At the edge of town to capture traffic directly from inter-urban and rural road networks before it enters the built-up area

- Close to main access routes to avoid added mileage by users diverting to reach site

- Away from residential areas to avoid disturbance to residents and abstraction of passengers from local buses 
- Where land is available since car parks take up a lot of space; good access to town center that is direct and un-congested with bus priority as necessary

- Possess a multi-purpose location for reverse P\&R in order to attract users in both directions enabling multi-purpose trips

Finally, the editor warned of several pitfalls to avoid. First, he suggested conserving the green belt land. Specifically, seek sites on lower grade land. Secondly, avoid too many sites. The editor also notes the need to minimize traffic congestion by avoiding routes through known bottlenecks. Furthermore, sites must not be too close to the town center since there would be little benefit from the mode change. It also calls for being aware of conflict with the site owner's primary business in shared sites.

\section{Lease Agreements}

The Federal Highway Administration report, Parking Management Tactics Volume III: A Reference Guide, contributes to the literature with their synopsis of criterion for a successful lease agreement. ${ }^{9}$ The authors assert that upon approaching the private property owners/managers, the lead-planning agency should have a preliminary policy for reimbursing or sharing some of the costs with the landowners. This would aid in alleviating the idea of adverse impacts to the private property and assuage the owners/managers fear of incurring additional cost of maintenance, operation, enforcement, insurance and related costs.

The report also noted that leasing agreements should contain certain elements. These include:

- Specific location of the site

- Time period of agreement and minimum termination notice periods

- Use of property and specific improvements to be made (e.g., lighting, signing, signals, markings and shelters)

- Access for vehicles and pedestrians

- Maintenance of facility

- Liability for injuries and damages

- Payment of leasing costs to property manager/owner

- Security

Leasing agreements should conform to state and local regulations. If possible, applicable local and state legal counsels should be involved in drafting, negotiating, and executing the agreements. The authors also provided illustrations of lease agreements that had been developed by Tri-Met, the transit agency in Portland, and the Ohio DOT. These can be found in Appendix A.

The Tri-Met Park and Ride Policy Report for January 15, 2001 addresses guidelines that the agency should utilize in the implementation of park and ride and shared use park and ride. The report suggests that despite the fact that landowners may seek reimbursement the agency should utilize one-time operating cost construction and enhancements or tax 
breaks and avoid annual operating cost in operating shared use park and ride. To reduce the possibility of negative impacts on landowners, intermingling between park and ride users and non-users should be discouraged.

Annual operating cost can include periodic or ongoing landscape maintenance, pavement repair, lighting and electricity, maintenance of signs and pavement markings, periodic or ongoing sweeping and garbage collection, security, advertising trade or promotions and additional liability insurance. Other possible incentives that can be utilized if the total cost does not exceed the one-time operating cost construction include installation of lighting, paving, installation of landscape, slurry seal, additional signage, and pavement markings.

\section{Limitations of Shared Use P\&R}

The Public Technology Inc. report, The Coordination of Parking with Public Transportation and Ridesharing, asserts that despite the benefits that can arise from shared use park and ride approach, several factors can diminish its benefits. Consequently, these factors must be analyzed prior to establishment. These include:

- Conflict between potential park and ride patrons and other users

- Local environmental concerns

- Existing traffic and travel hazards

Other factors that are of concern include who should operate the route and if new equipment should be purchased or existing equipment used. Operators can be the city, transit authority, or private carriers. The authors provide the example of the City of St. Paul, Minnesota to demonstrate how these concerns can be resolved. The authors note that the city established and expanded its free shuttle service from the city center to three shared use park and ride locations. The shuttles consisted of painted school buses that were chartered annually from a private operator for $\$ 190,000$. The riders paid between $\$ 1.00$ and $\$ 1.50$ to park their cars; this revenue covered one-fourth the cost of the shuttle's operating funds.

A FHWA report noted that use of shared use P\&R is intended to lessen duplication of parking supply and optimize the use of existing and new parking facilities. Yet despite its benefits, this report also identified limitations. ${ }^{10}$

- There are few instances where no conflicts exist in peak hours of parking for two or more uses

- There should be no long distances between the lot and one or more of the developments

- Enforcement of the joint use agreement through a land use covenant might scare off potential participants

The study by the Urban Land Institute also asserts that shared use park and ride has limitations. ${ }^{11}$ In their report, the authors studied the parking space demand characteristic 
of each component of mixed-use development and then estimated the effects on demand that occurred by combining these uses and eliminating duplications. Parking space demand characteristics for individual land uses (office, retail, restaurant, cinema, residential, hotel) were established to represent the maximum parking accumulation occurring on a given day. This relationship was displayed through hourly accumulation curves. The peak unit demand, hourly accumulation, and seasonal variation for each of the uses were examined. They concluded that the zoning code language does not cover all of the uses.

\section{Similar Projects}

Besides the literature focusing on P\&R arrangements, this study also reviewed literature on issues surrounding public transit access to commercial shopping centers including capital projects arrangements between commercial shopping centers and public transportation providers. Two major sources included a study by the Center for Urban Transportation Research entitled "Public Transit Access to Private Property" and the Florida Department of Transportation "State Park and Ride Lot Program Planning Manual".

\section{Public Transit Access to Private Property}

A study entitled "Public Transit Access to Private Property," focused on the legal rights of public transit agencies to access private property as well as major concerns of private property owners relating to public transit access. To identify concerns of private property owners, written surveys were administered to public transit providers and private property owners, developers and managers.

The most common responses given by the transit agencies in their interpretation of the major concerns of developers/private property owners included loitering and vehicle weight, followed in order of importance by crime, physical constraints, garbage, limited parking, fluid drippings, and fumes. The private property owners, developers and managers ranked loitering and the increased potential for crime as their top concerns, followed by physical constraints, pavement and curb damage caused by transit vehicle weight and limited parking. In addition, transit providers thought the installation of amenities was the most important incentive to offer, but private property developers/managers felt the most important incentive was cleaning the bus stop and surrounding area periodically.

The authors provided negotiation guidelines that can be used when transit is trying to gain access to private property. The first step of negotiation is to be aware of the economic benefits of on-site transit service. Benefits gained include ease of access and option for riders to choose between businesses in the complex. Furthermore, transit service helps businesses by increasing access to the labor pool and reducing tardiness and absenteeism. 
Being aware of the legislative actions that aid coordination is another step. These include Florida's Growth Management Act (Chapter 163, F.S.), which mandates that every local government prepare a comprehensive plan that specifies how they accommodate growth for ten years in the future. Depending on the size of the municipality or county, a mass transit element must be included. In addition to the Growth Management Act, local governments are required to adopt land development regulations (LDRs), which are consistent with the comprehensive plan. Transit agencies and local governments are urged to coordinate with each other during the development of the comprehensive plan and the implementation of land use developments. Transit Development Plan outlines the five-year plan of the transit agency. They are completed and updated every year by the transit agency.

There are two main methods that can be used to obtain transit accommodations on private property. The first method is regulatory, and the second is non-regulatory. According to the authors, regulatory methods require certain actions while non-regulatory methods encourage desired actions. The regulatory approach uses the following techniques to realize its objectives:

- Transit service areas are shown on a map and those properties within the service areas are subject to transit negotiation policies or regulations.

- Zoning which divides land into districts prescribing how the land may be used.

- Other land development regulations, which specify how and when transit accessibility standards, would be applied (e.g. bus stops and pedestrian circulation).

Non-regulatory methods rely upon good communication and negotiation skills. There are several approaches that can be utilized to help integrate transit into private developments:

- Incentives such as granting increased density or greater floor area ratio; lower parking requirements; decreasing impact fees; reducing trip generation rates; reduce taxes; and allowing greater flexibility in mitigation.

- Disincentives such as increasing design standards or fees if accommodations for transit access are not made.

- Other agreements could include possible concessions like maintenance, park and ride, bus stop in shopping center, customer amenities agreement, hold harmless agreement, and license agreement.

Moreover, when utilizing non-regulatory methods, development agreements should be legally drafted in a way that assures that each party complies. Joint development agreements, which specify how both public and private developers will contribute, should be sought. Another effective way of clearly documenting the role of each agency is to use a Memorandum of Understanding (MOU), which sets forth goals, objectives, actions, deadlines and funding responsibilities. 


\section{FDOT Planning Manual for Park and Rides}

Another related Florida -specific study about transit access to private property is the Florida Department of Transportation Planning Manual on State Park \& Ride Lots which describes the various techniques for involving the private sector in the development and operation of park and ride facilities. The manual catalogs fifteen techniques.

\section{Techniques}

The techniques are compared based on their implementation, legal, and institutional potential and possible potential for public cost reduction. Due to lack of relevancy to this report, transportation management associations and reduction in required spaces for provision of high occupancy vehicles at destinations are not discussed in detail.

\section{Joint Use of Shopping Center Lot}

Joint use of shopping center lots calls for implementing agencies to negotiate for the use of part of the parking area for park and ride. This partnership can be mutually beneficial in that it alleviates the cost of creating a parking lot for agencies, and shopping centers gain since it brings more clientele to their facilities. The department is responsible for the design and physical improvements and the shopping center may be responsible for maintenance of the public parking area, depending on the negotiations. Agencies utilizing this technique in Florida include the Metro-Dade Transit Agency, Jacksonville Transit Authority, Hillsborough Area Regional Transit Authority, Lynx formerly known as Tri County Transit (Orlando), LeeTran (Fort Myers), West Florida Regional Planning Council, and District VII Public Transportation Organization.

\section{Joint Use With Compatible Private Development}

This approach calls for public agencies to approach existing developments with adequate parking during the daytime hours to negotiate the use of part of the parking area for park and ride. The public agency becomes responsible for design, construction, and physical improvements while the private development provides land and maintenance. Benefits of this approach include very low implementation cost for the agency and a minimal operation cost due to the nominal lease amount. The private owner realizes monetary benefit for the development throughout the lease. Michigan Department of Transportation is the only known user of this approach.

\section{Joint Use of Local Agency Facility}

Joint use of a local agency facility means that the local government provides land to construct parking of which part is agreed to be used for park and ride while the remainder is used for another on-site public facility. The department's responsibilities include design, construction, and physical improvements while the participating agency's responsibilities include land and maintenance of the facility. 
This approach offers several benefits to participants. The department pays little since right-of-way purchase is not necessary. Even the community benefits since it receives improvement to public facilities at nominal cost. Agencies that have incorporated this approach include Metro-Dade Transit, the Hillsborough Area Regional Transit Authority, District III PTO, District VII PTO, and the West Florida Regional Planning Council.

\section{Joint Use on Land Provided by Nonprofit Organizations}

Joint use on land provided by nonprofit organizations entails public agencies approaching nonprofit organizations to negotiate the use of parts of parking areas for park and ride. Nonprofit organizations may include private colleges or universities, and fraternal organizations. This approach requires a lease or use agreement, and it may require public agencies to pay a premium for added liability coverage. The implementing department becomes responsible for design, construction and physical improvements while the nonprofit organizations are responsible for land and maintenance.

Benefits of this approach include low implementation cost for the public agency and slight monetary benefit to the nonprofit through lease payments. Furthermore, the nonprofit receives greater benefit if the public agency makes improvements. Two users of this technique include Southeast Michigan Area Regional Transit and the Michigan Department of Transportation.

\section{Sale of Surplus Right-of-way}

Sale of surplus right-of-way deals with the government unit negotiating park and ride lot construction in terms of the sale of surplus right-of-way. The department is responsible for selling surplus right-of-way of interest to developers, and negotiating the park and ride facility as sale terms for reduced sale price. Participants are responsible for purchasing the land and constructing the parking facility as sale terms for the reduced sale price.

Both the transportation departments and participants gain from this process. Departments don't pay anything in the liquidation of surplus property and construction of the facility since the land had already been purchased, while the developer acquires valuable property at reduced price. The Michigan Department of Transportation utilizes this technique.

\section{General Partnership}

General partnership incorporates the best attributes of each partner to establish parking facilities with maximum benefit to all parties. Responsibilities of public agencies include land acquisition and possible capitalization of while developers are responsible for buying facilities back from the State as development comes on line. The Department's only costs are related to land costs, while developers benefit from depreciation and equity of structures. 


\section{Developer Contributes Land Through Development Ordinance Mandates}

This technique entails large development dedicating land for a park and ride facility as a part of local development review process. Department responsibilities range from no involvement to design and construction depending on the development ordinance. The land would be in local government control and will require a joint participation agreement for the department involved. The participant is responsible for dedicating land specifically for a park and ride facility as part of the plat or site plan review process.

The price of land is eliminated from public development cost. There is also the potential of having the entire cost of the project supported by the developer, but this is contingent on the development ordinance and negotiations. Developers gain since they receive site approval. Other potential benefits include reduced road improvement assessments, satisfaction of concurrency requirement, or impact fee credits depending on the situation and ordinance. Hillsborough Area Regional Transit Authority is one example of this approach in action.

\section{Off-site Parking Substitute Process}

Unlike the developer contributing land through a development ordinance mandates approach, the off-site parking substitution process has more benefits. Benefits gained by using this approach include lower development cost for the facility. The developer receives site approval and reduced parking requirements. There are potential concurrency benefits for developers through reduction of traffic on congested roadways.

In this type of arrangement, parking requirements for new developments are reduced in lieu of the developer providing or funding parking off-site. It entails no responsibilities for the department, but developers are responsible for contributing to a parking trust fund or building off site parking. Some areas even require developers to provide shuttle service for off-site parking facilities located farther away than walking distances. Agencies that have incorporated this process are the City of Orlando Bureau of Planning and Zoning, City of Orlando Traffic Engineering, City of Sacramento Planning Department, Sacramento County Planning Department, Atlantic County Transportation Authority and the City of Los Angeles Zoning Department.

\section{Developer Impact Fee Assessments}

Developer impact fee assessments involve new developments supporting park and ride through payment of impact fee assessments. These can be based on the cost of park and ride facilities or may only be based on roadway improvement costs. Departments have no responsibilities, but participants are responsible for impact fees. Agencies that have used this process are the Hillsborough County Planning and Zoning Department, Broward County Office of Planning, and Palm Beach County. 


\section{Parking Condominiums}

Parking condominiums entail parking spaces at transit terminals reserved through joint or private department of parking with individual spaces being sold to parkers. Departments are responsible for planning, designing, condemning and construction, while participants are responsible for financing, management and, sales.

In this approach the ultimate users of the provided improvement pay most of the entire parking facility cost. The Urban Mass Transportation Administration now known, as FTA is the only known user of this approach.

\section{Establishing A Parking Authority to Develop Parking Facilities}

Basically, a public agency with bonding authority is established with powers to bond, condemn, construct, and manage parking facilities in a defined area. The state departments of transportations have no responsibilities, and the participants are responsible for establishing separate authority to administer parking in a defined area. One agency that has applied this process is the Downtown Tampa Parking Authority.

\section{Contracts With Private Provider For Transit Services}

This approach includes a private transit provider supplying service to a commuter lot at a reduced cost compared to locally supplied service. Departments are responsible for providing operating and capital funds in support of local transit operators. Participants are responsible for contracts with private providers and providing financing. Benefits gained include reduced cost to the transit operator in providing service to the facility. Agencies that have applied this process are the Metro Dade Transit Authority, Dallas Area Regional Transit Authority and Southern California Rapid Transit District.

\section{User Permits to Vendors at Park and Ride Lots}

This technique encourages increased facility usage to through provision of ancillary support services such as catering trucks, flower sellers etc to provide their services in the park and ride facility. Departments are responsible for granting use permits to vendors wishing to do business at parking facilities. Participants are responsible for licensed vendors providing services at facilities during commuting hours. This approach improves facility amenities at little cost, but may create problems with local retail establishments near the site.

\section{Observations}

Some techniques described above are better than others due to high implementation potential, minimal legal barriers, moderate institutional barriers, and significant potential for public cost reduction. These include joint use parking lots at shopping centers, joint use with compatible private use, joint use of local agency facilities and joint use with a nonprofit organization. Nevertheless, no one technique is the best for all situations. 


\section{Stakeholder Feedback}

\section{Survey of Organizations}

Along with the literature review, this synthesis includes feedback from transit agencies and P\&R managers. The goal was to supplement current literature with direct feedback, some of which may re-emphasize or negate findings from the literature. Furthermore, it was hoped that such feedback might shed some new light on existing issues or bring up new issues.

\section{Findings From Parking Managers/Private Property Owners}

Several private property managers were identified, but only a few were willing to participate. One respondent, a mall manager, indicated that there are three leasing agreements between the property and three transit agencies, and one leasing agreement with an apartment complex. One of the agreements allows the transit agency to have a bus stop on the mall property. The transit agency is required to perform periodic cleanings and maintenance of the stop. The second agreement allows the transit agency to drop off riders at the front of the mall and also allows riders to park on the top floor of the mall. The third agreement allows the private transit agency to disperse and collect riders at the front of the mall. The agreement with the apartment complex allows the residents to park at the mall.

When asked to rank the level of importance of certain impacts of transit when deciding whether to allow transit access to the property or to allow a shared use park and ride, the limited number of spaces, fumes from the bus, vehicle weight and dripping fluids were indicated most frequently. The respondent was also asked to rank the level of importance of incentives offered by transit to improve the working relationship. Periodic cleaning and maintenance of bus stops on site were ranked highest.

The private property owner was then asked about his level of experience with the customer base, revenues from leasing, transit service to the property, criminal activity, vandalism, littering/trash and space problems since allowing transit access and/or allowing a shared use park and ride on his property. The respondent indicated that the customer base had increased. There had not been any significant increase in littering/trash, criminal activity, or vandalism.

The responses from another mall manager were different. This respondent ranked liability and bus or auto accidents as the most important issues in deciding whether to allow/or continue to allow transit access to the property as well as whether to allow/continue to allow a shared use park and ride on the property. All other issues were ranked equally. Likewise, contrary to the other mall manager, the most important incentive that could be offered by transit to improve the working relationship between mall managers and transit was liability insurance. All other incentives were ranked equally. 
When asked about the level of experience with the customer base, revenues from leasing, transit service to the property, criminal activity, vandalism, littering/trash and space problems, the second respondent indicated that littering/trash had increased, followed equally by customer base, revenues from leasing, transit service to the property, and space problems. Vandalism and criminal activity were ranked equally as having no significant increase.

At least two respondents indicated that they were unaware of the existence of P\&R on their property. Several respondents attributed this ignorance to both the frequent change of ownership or management and the loss of park and ride agreements when properties change ownership or management. This is especially true of verbal agreements.

One shopping center respondent asserted, "It is possible that people park and then catch the bus from here. If too many people start using the shopping center lot as a park and ride, I would have the bus service there discontinued. Land in Tampa is too expensive and I won't use it for park and ride purposes."

\section{Findings From Transit Agencies}

Several transit agencies were contacted and asked if they had any formal or informal shared use park and rides. The respondents indicated they participated in thirty-seven shared use park and rides. These properties included two bus stations, nineteen shopping centers, one race track, a retirement home, one conference center, seven shopping malls, one stadium, two capital buildings, one home depot, one church and one museum. There were five confirmed formal agreements and five confirmed informal agreements. In terms of commercial center P\&R, eleven transit agencies indicated that they had at least one park and ride located at a commercial site. Those that answered with an affirmative were then asked for the list of sites and whether they were willing to participate in the survey. Despite numerous emails, letters and phones calls, a limited number of transit providers indicated a willingness to participate.

One private transit agency indicated that the agency provided service to a mall and a nursing home in the vicinity of the mall. The agency had a written agreement with the mall. The agreement permits riders to park on the top floor of the mall and permits the bus to stop and allow riders to get off and on at the entrance of the mall. When asked about how the idea of a shared-use park \& ride was marketed to the mall property manager, the respondent indicated the property manager was enticed with the assurance of more potential customers. However, when asked to comment on why property managers would be hesitant to allow transit access to the property, the respondent indicated that the agency could not answer for property managers. The respondent also indicated that the only incentive offered to the mall property manager was liability insurance.

One respondent from a public transit agency indicated that the agency had one park and ride at a community level shopping center and one at a commercial site that was not a shopping center, both through informal verbal agreements. This respondent also used the 
idea of more potential customers to market the park and ride to property owner/managers. When asked what incentives were offered to assure a better working relationship with property owners/managers, the respondent indicated that the transit agency offered installation of amenities as well as maintenance of bus stops on site. The respondent indicated that cost savings was the biggest benefit the transit agency gained from having a shared use park and ride The respondent commented that the most important issue in park and ride arrangements is usually the location of the bus stop in relation to the commercial property/shopping center, and that the more remote locations are preferable so that bus operations do not interfere with customers entering the facility.

Another interviewee when asked about the contact information for property managers/owners noted that the agreements were informal and some of the agreements were between single individuals that had asked and secured permission from the commercial sites. Consequently, there was no contact list.

Other respondents noted that there was a lack of coordination between transit agencies and private property owners or managers. Several respondents also indicated that they had informal agreements that have been in existence for years, but had not been addressed in recent years. Of the twenty-nine agencies contacted, four asked that the property managers not be contacted. This was due to fear that if the presence of the park and ride on the properties was brought to light, property managers would either renege, be uneasy about the presence of the park and ride, or demand further reimbursements.

In relation to the shopping centers, one respondent stated, "based on past experience, dealing with shopping centers is not a very reliable way to secure long term park and ride facilities. As a result, we are focusing more on buying and developing our own park and rides. Whenever possible, we look for other uses that can be combined with park and rides."

\section{Related Findings}

One rideshare respondent indicated that they did not negotiate the parking of vanpools; rather, the riders performed this task. The respondent also noted that they only interceded and negotiated parking of the vanpools in dire circumstances where riders failed to acquire permission to park due to developers or managers unwillingness. Also, the rideshare coordinator noted the existence of park and ride at various locations such as a Home Depot and several large grocery stores.

\section{Other Unanticipated Findings}

An interview with an amusement park revealed that it signed a contract with a private transit provider in another county to collect its prospective clientele from hotels in that county and take them to the amusement park. The amusement park also worked with the transit agency in their county to install bus stops at certain locations outside the fence and in other locations around the amusement park. The respondent also indicated the possibility of another agreement with a transit provider to take participants of the Sun and 
Fun flight festival to and from the park. Likewise, one mall has an arrangement that allows tour bus operators of the amusement park to park buses at the mall. In the case of rain or similar situations that cause early closure of the amusement park, riders would be transported to the mall in Tampa to do shopping.

Another unanticipated finding was the existence of the City of Orlando's Park and Play facility created in June of 1991. The facility allows patrons to park in the 550-vehicle space, drop off their kids at the 3500 square foot day care center, take the Meter Eater trolley to work, and visit the 7000 square foot area for upscale dining and entertainment. 


\section{Conclusions and Recommendations}

\section{Conclusions}

The central objective of this review has been to extract from surveys and existing literature those insights that will facilitate the relationship between transit agencies and private property developers/managers. Shared use park and ride is park and ride spaces that can be used to serve two or more individual land uses without conflict or encroachment. It is beneficial to both participants in that it alleviates the cost of creating a parking lot for public agencies while private developments gain since it brings more clientele to their facilities. There are two types of arrangements that can exist between property mangers/owners and transit agencies: formal and informal. The most common arrangement was informal, and this is due to a lack of, or minimal, communication between all involved parties.

Smooth coordination between property managers and transit agencies is possible. This can only be experienced if private property managers/developers, transit agencies, and governments work together. Nevertheless, the most general point derived from this review is that a clear channel of communication and thorough knowledge of issues pertaining to the relationship between transit agencies and private property managers/developers is necessary if shared use park and ride is to be successful.

The literature search revealed that responses to the questions about incentives suggest three key themes:

1. The majority of the concerns are related to the physical attributes of the transit vehicles and the damage that can be caused due to those attributes.

2. Maintenance is one of the most important incentives to developers, and also one of the most frequently given incentives provided by transit agencies. Consequently, this should be a focus area in negotiations.

3. There is need for education among the players in order to alleviate some of the misperceptions of transit services and patrons.

Feedback from private property owners/managers indicated that the most important incentives that can be offered to assure a better working relationship with transit agencies include installation of amenities, maintenance of stops on site, periodic cleanings, and concrete pads. Major concerns included:

- Perceived high levels of crime

- Ridership that was not part of their customer base

- Damage to asphalt

Feedback from transit agencies indicated that:

- Property managers, developers or owners are more inclined to agree to coordinate with transit agencies when they are assured of more potential customers

- There is not one single incentive that can be offered to private property developers, owners or managers. However, the highest ranked incentives include liability insurance, installation of amenities and maintenances of bus stops on-site. 
- Transit agencies may be reluctant to approach property managers due to a fear that property managers will say no or renege on past agreements.

\section{Important Challenges}

One of the most disappointing elements of this project was the limited existence of literature pertaining to shared use developments or shared use park and ride issues. Another problem was the lack of interest in the survey expressed by both property managers/owners and transit providers. The sample population was contacted by three mediums-letters, emails and telephone. However, several of the population failed to respond, and those that did participate had to be pressured into participating.

The literature on shared use park and ride indicated the following challenges:

- There are few instances where no conflicts exist in peak hours of parking for two or more uses; and attempts to enter a formal joint use parking agreement might scare off potential participants.

- The costs of constructing and operating parking facilities of all kinds are high

- Likewise, other possible barriers have included finding adequate transit service, rideshare programs, suitable incentives and perceived security concerns.

- Several factors must be considered prior to the implementation of shared use park and ride. These include possible conflict between potential park and ride patrons and other users; existing traffic and travel hazards; and zoning code language that does no always cover all of the potential techniques.

- Barriers to effective implementation include the fact that shopping centers are generally difficult to deal with, and are often uncooperative. In addition shopping centers may not have been originally designed for transit, which could preclude transit access to the site.

- Developers tend to want to sign long-term leases that might not be practical for transit since shared use park and ride lots are created based on demand from public whose demands fluctuate. .

Shared use P\&R has many benefits and some limitations. However, the limitations can be overcome, and the benefits outweigh the limitations. To be successful though, future land use and development decisions must be made with public transportation in mind. Parking and other policies should enhance rather than detract from public transportation potential.

\section{Recommendations}

Several ideas to promote shared use park and ride are recommended, ranging from improved communications between public and private parties to jurisdictional incentives. A better understanding of the nature of shared $\mathrm{P} \& \mathrm{R}$ along with its inherent opportunities by decision makers in the transit agencies and developers/retailers may help eliminate some of the communication problems. 
Literature on shared use park and ride was analyzed around issues of economic benefits and operation. In all cases, certain aspects were similar and effective, which made the cooperation process between the transit agency and the property manager/developer work. The first step is early contact with the local government to explain the proposed coordination and gain support. Try to get the government to offer incentives such as parking reductions if the developer/manager is willing to participate. Having government support reduces the likelihood that the manager will want to renege on the agreement. The second step utilized was approaching the property developer/manager. In this phase, the potential benefit of increased customers and an increased work pool should be emphasized. Likewise, the transit agency should try to offer maintenance and periodic cleaning of the bus stop. If the developer/manager agrees, the next pivotal step is to sign a legal enforceable agreement of some kind. Lastly, try to get the developer/manager involved in the designing of routes, location of stops and possible passenger amenities.

\section{Future Needs}

A review of the experience to date indicates the future development of shared use Park and ride would be facilitated in the following ways:

1. Improved technical information on shared use park and ride (both developers and policy makers may continue to have reservations about moving forward with such provisions unless clear evidence is presented of potential benefits and the likelihood of success of the program).

2. Creation of an educational process to familiarize key groups with the purpose and benefits of shared use Park and ride.

3. Better methods of providing assurances that commitments will be fulfilled without unduly discouraging private property owners/managers from participating in shared use Park and ride.

4. Continual updating of information for shared use Park and ride nationwide and dissemination of information on the subject as it becomes available. 


\title{
Appendix A
}

\section{Sample Park \& Ride Contracts}

\author{
PARK AND RIDE FACILITY LEASE AGREEMENT \\ FOR PORTLAND, OREGON
}

This agreement, dated , between the Tri County Metropolitan

Transportation District of Oregon, and (Owner).

1. Purpose. The purpose of this Agreement is to provide Tri-Met with the use of part of Owner's premises as a park and ride and carpooling facility for the benefit of Tri-Met's patrons and persons in carpools.

2. Premises. Owner hereby licenses Tri-Met to use for park and ride and carpooling purposes that portion of Owner's premises marked "Park and Ride" in Exhibit "A" hereto (hereinafter called "Premises") .

3. Term. The term of this Agreement shall be party, however, may terminate this Agreement after years from date hereof. Either months by giving months notice to the other party of its intent to terminate.

4. Use of the Property. Tri-Met may use the Premises for a park and ride facility for TriMet and its patrons, and for a carpooling parking facility; vehicle access and parking for Tri-Met patrons and persons in carpools; marking of the Premises; and all similar and related uses. TriMet will be the owner of all improvements it places on the Premises, but will obtain the Owner's written approval before placing any improvements on the Premises.

5. Access. Tri-Met may use the Owner's property surrounding the Premises for vehicle and pedestrian access and circulation for Tri-Met and its patrons, excluding buses, and persons in carpools.

6. Marking of Premises and Publicity. Tri-Met may mark the Premises, and will install a sign indicating that the Premises are available for Tri-Met patrons and persons in carpools as a result of Owner's courtesy. Tri-Met will obtain Owner's written approval before placing any improvements on the Premises.

7. Maintenance. Tri-Met will provide reasonable maintenance for the Premises and improvements thereon. Owner agrees to notify Tri-Met promptly of defects in parking areas which could give rise to third party injury or even though Tri-Met may make periodic inspections of the Premises.

8. Governmental Charges. Tri-Met will have no obligation to pay any taxes, assessments, or governmental charges against the Premises.

9. Liability. Tri-Met will hold Owner harmless from all claims, damages, losses and expense arising out of Tri-Met's installation, maintenance and permissible use of the park and ride facility.

10. Termination. On termination of this Agreement, Tri-Met will surrender use of the Premises to Owner, will remove all signs and structures placed on the Premises by Tri-Met, and will repair any damage to the Premises caused by the removal.

OWNER

$\underline{B y}$

Title

Property Address
TRI-COUNTY METROPOLITAN TRANSPORTATION DISTRICT OF OREGON

By

Director of Contract Administration 
SAMPLE PARK AND RIDE FACILITY LEASE AGREEMENT FOR OHIO IN THE MATTER OF THE ESTABL ISHMENT AND OPERATION OF A PARKING FACILITY AGREEMENT NO . BY THE (AGENCY) ON PROPERTY OF (OWNER) AT (LOCATION)

THIS AGREEMENT made this day of , 19 , by and between (Name of Agency) hereinafter referred to as "AGENCY" and (Company, Person, or other entity owning property) hereinafter referred to as the "OWNER".

\section{WITNESSETH,}

WHEREAS, the AGENCY has determined it to be in the public interest to establish a staging area in the vicinity of (describe general location) for persons interested in participating in Park-and-Ride transportation operations, and WHEREAS, the parties hereto have found the premises of the OWNER to be suitable for the establishment and operation of a staging area to provide space for pickup and discharge of high occupancy vehicle passengers and for the parking of private vehicles of passengers participating in the Park-and-Ride program, and

WHEREAS, it is the desire of the parties hereto to carry out and accomplish the establishment, operation and maintenance of a Park-and Ride staging area on property of the OWNER and to determine and agree upon the manner of doing the work and the responsibilities of each of the parties hereto.

NOW, THEREFORE, for and in consideration of the mutual covenants hereinafter stipulated to be kept and performed, it is agreed between the parties hereto as follows

\section{SECTION I.}

The OWNER hereby agrees to make available to the AGENCY that portion of the OWNER'S property shown on the drawings attached hereto and marked as Attachment "A" for use by the AGENCY for construction, operation and maintenance of a Park-and-Ride facility, and such other of the OWNER"S property as may be necessary and mutually agreed upon by the parties hereto, as access to the said Park-and-Ride facility.

In exchange for this right to use, the AGENCY agrees to pay to the OWNER the sum of on the date this agreement becomes effective, and the sum of each (month) (year) thereafter until this agreement is terminated.

The AGENCY shall take out and keep in effect a policy of insurance in the name of the AGENCY and COMPANY, jointly, to protect both the AGENCY and COMPANY against loss or damage to property and injury to or death of persons, and against all claims, demands, suits, expenses and/or judgments arising because of, or resulting from, the construction, operation and maintenance of the Park-and-Ride facility.

Such policy of insurance to provide single limit coverage of $\$ 1, \mathrm{OOO}, \mathrm{OOO}$ for bodily injury and property damage per vehicle per occurrence.

\section{SECTION II.}

The work to be done under the terms of this agreement and shown on the plans attached hereto and made a part of this agreement as Attachment "A", consists of the alteration of certain properties of the OWNER for operation and use by the AGENCY as a staging area for persons traveling in buses, carpools and other ride-sharing vehicles. Said staging area commonly referred to as the Park-and-Ride facility.

\section{SECTION III.}

Responsibility for the several necessary items of work shall be as follows: 
(a) The following work shall be done or caused to be done by the AGENCY at its own cost and expense, subject to the provisions) of this agreement.

1. Furnish and erect signs designating the Park-and-Ride facility.

2. Furnish and install pavement markings, parking stops, as necessary to enhance traffic operations.

3. Erect fencing as shown on the plans to provide security for the facility.

4. Furnish and install necessary lighting fixtures including furnishing power thereof.

\section{SECTION IV.}

The AGENCY shall provide reasonable maintenance for the Park-and-Ride facility including all improvements made by the AGENCY, and shall make periodic inspections to determine the extent of any defects which may require maintenance or repair.

The OWNER agrees to notify the AGENCY promptly of any defects in the Park-andRide facility which could give rise to third party injury or damages.

It is agreed between the parties hereto that the AGENCY may arrange with and obtain the services of local police agencies to enforce parking regulations within the Park-and-Ride facility, including the removal of improperly parked or abandoned vehicles.

\section{SECTION V}

This agreement shall become effective upon execution by the parties hereto and shall remain in effect so long as the AGENCY continues to operate the Park-and-Ride facility in accordance with the terms herein set forth and shall be binding on the successors or assigns of either or both parties. Providing, however, that after the first anniversary of this agreement, either party hereto may terminate the agreement by notifying the other party in writing by certified mail, thirty (30) days in advance of the proposed date of termination.

Upon termination of this agreement, the AGENCY shall have an additional thirty (30) days in which to cease operations and restore the property to its original condition or as may be agreed to by the OWNER in writing.

IN WITNESS WHEREOF, the parties hereunto have caused this agreement to be executed in duplicate as of the day and year first above written.

(Name of Agency)

By: (Title)

(Name of Owner)

By:

(Title)

Property Address 


\section{Appendix B}

\section{Sample Survey Questionnaires \\ Survey of Managers of Park and Ride Parking Lots \\ Center for Urban Transportation Research, University of South Florida}

Dear Manager:

The purpose of this survey is to quantify the level of benefits and costs of using the parking lot for Park \& Ride purposes as well as determining the feasibility of making such arrangements. To the best of your knowledge, please check those that apply.

1) What type of private property (ies) do you manage?

Facility Type

Check all that Apply

Regional shopping center

Community-level shopping center (Walmart, Kmart)

Neighborhood-level shopping center (supermarket and minor tenants)

Regional office parks

Mixed-use development/industrial parks

Other

2) Please rank the level of importance of the following issues in deciding whether to allow or continue to allow a Park \& Ride lot on your property.

Liability

Limited \# of parking spaces

Bus/auto accidents

Vehicle weight

Dripping fluids

Garbage associated with riders

Fumes from bus

Perceived threat of crime

Complaints from tenants/customers

Other
Level of Importance

Most

Not

$\underline{\text { Important }} \leftrightarrow$ Important $\leftrightarrow$ Important

\begin{tabular}{|c|c|c|c|c|}
\hline 5 & 4 & 3 & 2 & 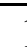 \\
\hline 5 & 4 & 3 & 2 & \\
\hline 5 & 4 & 3 & 2 & \\
\hline 5 & 4 & 3 & 2 & \\
\hline 5 & 4 & 3 & 2 & \\
\hline 5 & 4 & 3 & 2 & \\
\hline 5 & 4 & 3 & 2 & \\
\hline 5 & 4 & 3 & 2 & \\
\hline 5 & 4 & 3 & 2 & \\
\hline 5 & 4 & 3 & 2 & \\
\hline
\end{tabular}


3) Please rank the level of importance of incentives that could be offered by a transit provider to improve the cooperative working relationship.

Liability insurance

Installation of concrete pads

Free advertisement space

Maintenance agreements

Installation of amenities

Periodic cleaning

Maintenance of bus stops on site

Other
Level of Importance Most

$\underline{\text { Important }} \leftrightarrow \underline{\text { Important }} \leftrightarrow \underline{\text { Important }}$

5

$\begin{array}{lllll}5 & 4 & 3 & 2 & 1\end{array}$

$\begin{array}{lllll}5 & 4 & 3 & 2 & 1\end{array}$

$\begin{array}{lllll}5 & 4 & 3 & 2 & 1\end{array}$

$\begin{array}{lllll}5 & 4 & 3 & 2 & 1\end{array}$

$\begin{array}{lllll}5 & 4 & 3 & 2 & 1\end{array}$

$\begin{array}{lllll}5 & 4 & 3 & 2 & 1\end{array}$

$\begin{array}{lllll}5 & 4 & 3 & 2 & 1\end{array}$

4) Since allowing a Park \& Ride on your property, rank the level of your experience with the following:

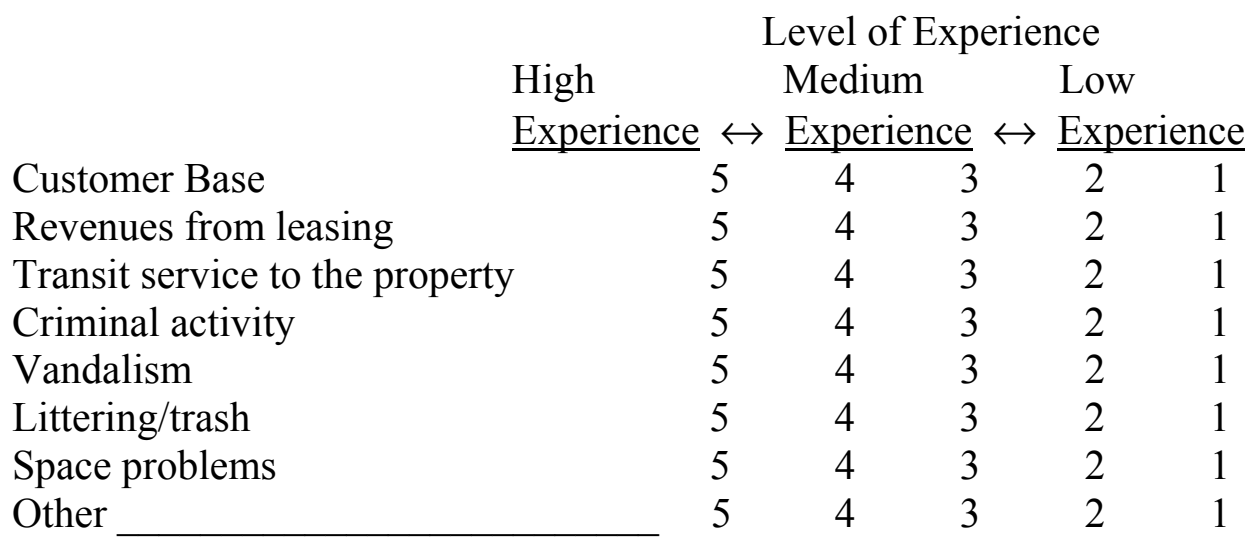

5) Have you incurred any added financial costs due to the Park \& Ride?

Yes_ No

*If yes, please explain.

6) Please share any "Lessons Learned" from relationships with public transportation systems. 


\section{Survey of Transit Service Providers with Shared Use P\&Rs Center for Urban Transportation Research, University of South Florida}

Dear Transit Service Provider:

The purpose of this survey is to quantify the level of benefits and costs of using shopping center parking lots for Park \& Ride purposes as well as determining the feasibility of making such arrangements. To the best of your knowledge, please check those that apply.

1) What type of private property (ies) are your shared-use Park \& Rides located at? (Input the \# of locations by type for all that apply).

Facility Type

Number of Properties

Regional shopping center

Community-level shopping center (Walmart, Kmart)

Neighborhood-level shopping center (supermarket and minor tenants)

Regional office parks

Mixed-use development/industrial parks

Other

2) What type of arrangement/agreement do you have with the property manager(s)?

Formal written agreement

Check all that Apply

Informal verbal agreement

Free use of property

Leasing arrangement

Other

3) How do you market the idea of a shared-use Park \& Ride to property managers?

More potential customers

Check all that Apply

Free advertising

Public recognition

Reduced traffic congestion

Environmental benefits

General benefit to the community

Other 
4) Please rank the level of importance (in your opinion) of the following issues in property managers' decision of whether to allow or continue to allow a Park \& Ride lot on their properties.

$$
\text { Most Level of Importance } \quad \text { Not }
$$

Liability

Limited \# of parking spaces

Bus/auto accidents

Vehicle weight

Dripping fluids

Garbage associated with riders

Fumes from bus

Perceived threat of crime

Complaints from tenants/customers

\begin{tabular}{|c|c|c|c|c|}
\hline 5 & 4 & 3 & 2 & 1 \\
\hline 5 & 4 & 3 & 2 & 1 \\
\hline 5 & 4 & 3 & 2 & 1 \\
\hline 5 & 4 & 3 & 2 & 1 \\
\hline 5 & 4 & 3 & 2 & 1 \\
\hline 5 & 4 & 3 & 2 & 1 \\
\hline 5 & 4 & 3 & 2 & 1 \\
\hline 5 & 4 & 3 & 2 & 1 \\
\hline 5 & 4 & 3 & 2 & 1 \\
\hline 5 & 4 & 3 & 2 & 1 \\
\hline
\end{tabular}

Other

5) What incentives do you offer to property managers/developers to assure a better working relationship?

Liability insurance

Check all that Apply

Installation of concrete pads

Free ad space

Maintenance agreements

Installation of amenities

Periodic cleanings

Maintenance of bus stops on site

Other

6) What benefits have you gained from your experience with shared use Park \& Ride?

Increased ridership levels

Check all that Apply

Customer satisfaction

Cost savings

Community visibility

Other

7) What criteria do you use to select shared use Park \& Ride locations?

8) Please share any "Lessons Learned" from your relationships with private property managers/developers. 


\section{Appendix C}

\section{Listing of Service Providers:}

Brevard County (SCAT)

Miami-Dade Transit

Orlando (LYNX)

Manatee County (MCAT)

Gainesville (RTS)

Pinellas County (PSTA)

Hillsborough County (Hartline)

Lee County (Lee Tran)

Sarasota County Area Transit (SCAT)

Jacksonville Transportation Authority (JTA)

Tallahassee Area Regional Transit (TALTRAN)

Veterans Administration (VA)

University of South Florida Shuttle (USF Bull Runner)

\section{Listing of Parking Managers}

University Mall

Home Depot

UF Conference Center

Kmart

Wal-Mart

Museum at University of Florida

Downtown Bethel Bus Station

Hartline Transfer Center

Capital Building

Publix

BJ Wholesale Clubs 


\section{Appendix D}

Framework for Shared Use P\&R Analysis:

Strategies for Planning and Managing Shared Use P\&R Facilities

\section{What are Shared Use P\&R Facilities}

Define P\&R facilities

Types of P\&R facilities

Explain Shared Use P\&R facility

Where to Find Potential Shared Use P\&R Facilities

Shopping malls

Religious facilities

Movie theatres

Schools/daycare

DOT public right of way areas

Underused parking lots

Suburb businesses

Industrial area warehouses

How to Select and Retain Shared Use P\&R Facilities

Service planning information

Existing routes

Planned routes

Community interest/request

Assessment criteria

Incentive options

Liability insurance

Provider promotional opportunities

Public recognition

Public acknowledgement

Acknowledgement on sign

Who Benefits from Shared Use P\&R Facilities

1. The Transit Agencies

a. Benefits

i. Ridership

ii. Security

iii. Community visibility/presence

iv. Cost saving

$$
\text { - Cost estimates for built P\&Rs }
$$

b. Problems

i. Availability

ii. Liability

iii. Provider security perception

iv. Intermittent demand

- Seasonal

- Events 
2. The Facility Provider

a. Benefits

i. Potential customers

ii. Cost sharing

iii. Transit service

iv. Potential security (abandonment perception)

$\mathrm{V}$.

b. Problems

i. Perception of security problems

ii. Local circulation traffic problems

iii. Intermittent demand

- Seasonal

- Events

3. The Community

a. Benefits

i. Transit service

- Availability of local service

- Access to direct service

ii. Trip chain reduction

iii.

b. Problems

i. Perceived security problems

ii. Local circulation traffic problems

iii. Limited parking opportunities

4. Local jurisdiction

a. Benefits

i. Regional road capacity management

ii.

b. Problems

i. Local street capacity improvement needs

ii.

5. Public effects

a. Benefits

i. Environmental effects

ii.

b. Problems

i. 


\section{Footnotes}

${ }^{1}$ Kidder, L. H., and Fine, M. "Qualitative and Quantitative Methods: When Stories Converge." In M.M. Mark and R. L. Shotland (eds.), Multiple Methods in Program Education. New Directions for Program Evaluation, no. 34 San Francisco: Jossey-Bass, 1987

${ }^{2}$ Light, R. J. and Pillemer, D, B. Summing Up: The Science of Reviewing Research. Cambridge, Mass.: Harvard University Press, 1984

${ }^{3}$ Barton-Aschman Associates Inc. "Shared Parking Demand for Selected Land Uses." Urban Land, September 1983

${ }^{4}$ Federal Highway Administration. Parking Management Tactics Volume III: A Reference Guide. Washington D.C.. Federal Highway Administration, 1981

${ }^{5}$ Public Technology Inc. "The Coordination of Parking with Public Transportation and Ridesharing." Urban Consortium Information Bulletin, June 1982

${ }^{6}$ Smith, Steven. "Park and Ride at Shopping centers: A quantification of modal-shift and economic impacts." Transportation Research Record 908, 1983

${ }^{7}$ Smith, Wilbur. "What's New in Parking." Planning, 1983

${ }^{8}$ Editorial, "Best Park and Ride Lots I." The Urban Transportation Monitor, April 13, 1990.

${ }^{9}$ Editorial, "Best Park and Ride Lots II." The Urban Transportation Monitor, April 27, 1990.

${ }^{10}$ Federal Highway Administration. Parking Management Tactics Volume III: A Reference Guide. Washington D.C.: Federal Highway Administration, 1981

${ }^{11}$ Barton-Aschman Associates Inc. "Shared Parking Demand for Selected Land Uses." Urban Land, September 1983 